\title{
3 Deportation regimes in the post-Soviet space
}

\section{Producing deportable migrants in the Russian Federation}

\author{
Rano Turaeva and Izzat Amon
}

\section{Introduction}

Central Asian labour migration to the Russian Federation (hereafter, Russia) reached its peak in the early 2000s. Estimates for the number of migrants currently residing in Russia reach at least 10 million (including unofficial figures). ${ }^{1}$ As a result, the Central Asian economies became remittance-dependent, such that more than half of Tajikistan's GDP is sourced from remittances primarily from Russia. The Russian migration infrastructure was unprepared to accommodate such a massive influx of labour migrants, creating spaces for flexible legal strategies exercised by decision-makers within the justice system as well as security services. The latter use the legal and economic precarities of migrants, who, in turn, also attempt to deal with their semilegal, quasilegal, illegal and kind-of-legal situations as deportable and detainable at any time.

Migration studies, studies of transnationalism and globalisation represent a big body of literature, which has shifted depending on the dynamics of migration and mobilities. More recent studies of migration emphasised blurring national boundaries, the transnationalisation of the migration experience, politics and economies, whilst the securitisation of national borders and policing migration have also intensified (Glick Schiller et al. 1992; Appadurai 1996; Hannerz 1996; Gupta and Fergusson 1997; Vertovec 2009). This chapter contributes to migration studies by focusing on legal issues and deportation regimes as well as the experiences shaped by the deportability and detainability of migrants in Russia, in keeping with the work of De Genova and Peutz (2010) and De Genova (2019). The questions we consider here are as follows: How is deportability legally produced and operationalised? What legal and illegal means are used to render migrants deportable? And what does being deportable mean for the daily survival of migrants in Russia?

We argue that the result of not having a clear regulatory basis for making decisions about deportation as well as for legally violating laws during the deportation process result in chaos within the management of migration and mobility. We also argue that these gaps and contradictions within the legal system serve as both means and opportunities for Russian officials to illegally expel unwanted migrants from Russia. Namely, these gaps and contradictions result in the use and abuse of

DOI: $10.4324 / 9781003176763-3$ 
deportation as a weapon or punishment, in accordance with findings from Walters (2018) and Navasky (1959). The overall analysis of the practice of deportation and violating the human rights of migrant-victims indicates and supports the findings of De Genova and Peutz (2010), whereby deportability and detainability are produced and experienced.

It is not only contradictions and gaps within the legal system that create opportunities, but, also, the impunity of employees who overstep their privileges and responsibilities. This includes individuals who, for example, enjoy free access to databases they may manipulate if necessary. Such opportunities grant state officials rights over the lives and livelihoods of many labour migrants. The contradictory and paradoxical characteristics of Russian legislation relate to the deportation regime itself, where it is clear that legal provisions are not necessarily followed within that process, including the speed of the actual execution of a deportation order.

The continuous state of deportability and detainability leaves migrants vulnerable to various kinds of exploitation and violence, maintaining migrants' dependence upon those in power. Mobility, migration and uncertainties represent the central topics of this chapter, contributing further to the general discussion surrounding informality and mobilities (Hart 2006; Urry 2012; Urinboyev and Polese 2016; Turaeva 2013, 2014, 2018). Mobility, uncertainty and authoritarian governments are preconditions to the establishment of deportation regimes in a Foucauldian (Foucault 1975, 1980) understanding of the regime as a dispersed but powerful set of institutions, practices and objects. Power is central to the functioning of any regime, and Foucault's recommendation is to 'escape from the limited field of juridical sovereignty and State institutions, and instead base our analysis of power on the study of the techniques and tactics of domination' (Foucault 1980: 102). In other words, power is constituted through strategies, dispositives, techniques and the economy (Foucault 1980).

This chapter, then, contributes to an understanding of how uncertainties are produced through a continuous state of deportability and how mobility or a limitation to it leads to the violation of basic human rights related to mobility and the freedom of movement (Turaeva 2013). The informal and, at times, illegal use of rules and laws to practice deportation also show how much flexibility is possible within Russian legislation in order to easily punish those unwanted or, to use the wording in Russian legal texts, 'undesirable' (nejelatelnost ') (The Federal Law, latest version from 07.04.2020 № 111-FZ).

In this chapter, we present an analysis of Russia's judicial and political system related to the regulation and administration of migrants, focusing specifically on Central Asian migrants. Our analysis includes an examination not only of laws and practices implemented by government bodies and politicians but also individual examples of deportation cases derived from the second author's work as an attorney. Here, we pay particularly close attention to the legislative changes related to the regulation of deportation and analyse the conditions of the deportability of migrants relying on the theoretical traditions of Agamben (1998), De Genova and Peutz (2010) and Foucault (1975, 1980). 
The policies we discuss in this chapter concern the migration management efforts of the government and its legislative basis. We also discuss the individual experiences of victims and victims' supporters, their families; the daily strategies of migrants living in fear of being deported; and other norms, institutions and practices which form the deportation regime in the post-Soviet space. Various actors within the deportation regime are presented, and we discuss different practices from within the deportation regime in order to understand how deportability is produced, conducted and experienced.

We collected the data for this chapter collaboratively, whereby both authors participated in deportation cases filed in Russian courts against migrants. Specifically, the second author represented the migrants as their lawyer. The first author participated in the deportation case hearings and conducted interviews with migrants in Moscow within the framework of her field research in 2016 and 2017. The first author, employing anthropological methods of field research, conducted both recorded interviews and unrecorded interviews, informal conversations, discussions and follow-up contacts via mobile communication channels through the present. The second author works as a lawyer and human rights activist for migrants' rights and is based in Moscow. Therefore, the data consist of not only research data in the form of the direct observation of deportation cases in courts in Moscow and interviews with migrants in Moscow (clients of the second author) but also official documents submitted to the court as part of the deportation cases in which the second author played a role. The names of the migrants presented here have been changed as well as the locations of the court cases to ensure the anonymity of all participants.

This chapter is structured as follows to address the research questions and advance our arguments. First, we provide background information on the migration situation in Russia, situating our analysis within the migration studies literature. We then outline the legal basis of the migration administration and migration politics in Russia, followed by specific deportation case studies. These case studies are followed by our analysis of the regulation of deportation applied in Russia and an analysis of the entire deportation regime in Russia as regulated, practised and experienced by different actors participating in this regime. Our concluding remarks outline our arguments and indicate future gaps which need to be addressed in the research and policy work concerning deportation regimes globally.

\section{Migration to Russia: numbers and laws}

Migration studies, studies of transnationalism and globalisation itself all emphasise increasingly blurred national boundaries, whilst the securitisation of national borders and policing migration simultaneously intensified (Walters 2002; Guild 2009; Tsing 2005; Glick Schiller et al. 1995; Appadurai 1996; Hannerz 1996; Gupta and Fergusson 1997; Vertovec 2009). Furthermore, Vertovec (2009) emphasised that the precondition for the expansion of processes related to migration stemmed from the development of a means for quick communication. 
With more recent moves in globalisation studies, researchers began questioning social and political boundaries and fixed identities. They focused on the processes of deterritorialisation and the marginalisation of nation-states in a mobile and interconnected world (Appadurai 1996; Gupta and Fergusson 1997). Later, the critique of this approach prompted discussions of reterritorialisation and reordering the global world, bringing nation-states 'back in' as important actors (Braithwaite 1992; Cutler et al. 1999; Slaughter 2004; Appadurai 2006; Djelic and Sahlin-Andersen 2006). Some authors focused on the reordering process itself, enquiring into how the genesis and structuring of new modes of governance (conceptualised as practices of rule and regulations) frame and reproduce order (Djelic and Sahlin-Anderson 2006: 3). Reordering, placing the state back into the equation, associated with general trends amongst state powers aimed at controlling migration in light of global right-wing populism and antimigrant attitudes more generally (Bigo 2002; Calavita 2005; Chavez 2008; Cole 2002; Cornelius et al. 1994; Doty 1998). There is by now a large body of literature dealing with the state and securitisation of immigration and migration (Ellermann 2009; Fassin 2011; Krause \& Williams 1996; Nevins 2002; Simon 1998; Stumpf 2006; Welch 2002, 2006; Willen 2007; Williams 2003).

Central Asians have migrated en masse to other countries, particularly to Russia, in search of better work opportunities and living conditions (Urinboyev 2019; Turaeva 2018; Schenk 2020; Heusala and Aitamurto 2016). Russia is the fourth-largest recipient of migrant workers in the world, whilst Central Asia represents one of the regions whose economy depends increasingly on remittances sent from abroad (IOM 2005: 397). The official numbers given by the Russian statistical agency, Rosstat, from 2011 to 2017 indicate that about three to four million migrants entered Russia, with unofficial numbers estimating twice as many migrants due to restrictions to official residence permits, which we describe below. ${ }^{2}$ As a reaction to these rapid developments, Russia introduced restrictive rules and policies to control mobility and migration, particularly in big cities such as Moscow and St. Petersburg. These rules and policies include policing migrants, and the administration of residence, labour and taxation along with various conditions governing them. Migration policies across all post-Soviet Republics have been renewed to fit the novel conditions of becoming independent states, aimed at ensuring state sovereignty and securing national borders. However, under the regulation within agreements amongst the post-Soviet Republics, a union known as the Commonwealth of Independent States (CIS), mutual agreements exist on labour mobility, economic cooperation and security issues.

Russian migration regulation following its independence was challenged by mass migration from other post-Soviet Republics. Such laws were developed gradually, fitting the dynamics of the migratory processes as well as the political and economic situation within Russia. Regulation of migration was organised and administered after the collapse of the Soviet Union through the creation of a state body, known as the Federal Migration Service (FMS) in 1992. FMS was a federal law enforcement agency, responsible for controlling, administering, investigating and governing migration (both internal and international) and mobility both 
within and outside Russia (Turaeva 2016). FMS occupied a higher-ranking position as an institution within the migration control system and was more powerful than agencies such as the police department. On 5 April 2016, FMS was closed down and its functions were transferred to the Main Directorate for Migration Affairs within the Ministry of Internal Affairs ( $M V D$ a local abbreviation), a state agency that provides security and is less powerful than the Federal National Security Services, which belongs to the Ministry of Defence. This last development within migration governance in Russia implied that mobility and residence were reformulated, relegislated and securitised, specifically such that migration control became an issue considered within security offices such as $M V D$ (that is, the police and justice system). This represented a significant move, illustrating the complexities of power games played within the governing regimes in Russia (Ledeneva 1998, 2006). Details regarding the political machine of migration management in Russia, another understudied field, lie beyond our scope here. Instead, we focus on one of the many tools of this machine or apparatus, namely, the deportation regime. Specifically, we begin by outlining the legal basis of the deportation regime in order to understand through what means security officials operate in order to manage, control and benefit from migration.

\section{Deportation regime: the legal basis}

Federal Law No. 114, 'On the Order of the Exit and Entry to the Russian Federation', and Federal Law No. 115, 'On the Legal Status of Foreign Citizens in the Russian Federation', were adopted in August 1996, with further changes to them introduced regularly, often annually (The Federal Law, latest version from 07.04.2020 № 111-FZ). However, based on the second author's experience as a lawyer based in Moscow, the actual implementation of these laws only began in 2013. This can be explained through the migration dynamics in Russia, whereby the influx of migrants skyrocketed during the late 1990s, with the general situation becoming difficult to manage towards 2010 and more so during the economic crisis (2008) following the introduction of sanctions against Russia after 2014 (due to the annexation of Crimea). The wording of the law regulating the exit and entry to Russia deserves special attention here: 'reshenye o nerazreshenii vèzda v Rossiskuyu Federaziyu ili resheniye $o$ nejelatelnosti prebyvania (projivaniya) v Rossiskoy Federazii', literally translated into English as 'a decision on non-permission to enter the Russian Federation or a decision on the undesirability of a stay (residence) in the Russian Federation'. Essentially, this refers to regulating permission to enter the territory of Russia (a priori to migration) and/or the wishes (desire vs undesirability) of the state towards a migrant. Permission to enter would or could be equated with regulating entry or issuing visas, which would apply to those who wish to enter Russia. Therefore, the condition for this decision cannot logically result in any charges (administrative or criminal) against de facto residing migrants. The part regarding the desirability of migrants cannot be legally measured vis-à-vis how one becomes undesirable or desirable and wishes cannot be regulated from 
the sociological point of view. The semantic contradiction of this law already, to our minds, allows much room for interpretation and abuse, as well as the possibility of producing undesirability, and, thus, deportability and detainability. The law further states:

The deportation of a foreign citizen or stateless person with respect to whom a decision was made to not allow entry into the Russian Federation or a decision on the undesirability of staying (living) in the Russian Federation is carried out by the federal executive body in the field of internal affairs or its territorial body in collaboration with other federal bodies, executive authorities and their territorial bodies within their competence. The procedure for interaction between the federal executive body in the field of internal affairs and its territorial bodies with federal executive bodies authorised to make a decision on non-permission to enter the Russian Federation or a decision on the undesirability of staying (living) in the Russian Federation, and their territorial bodies when exercising control over the execution by foreign citizens and stateless persons, such decisions are established by joint regulatory legal acts of the federal executive body in the field of internal affairs and interested federal executive bodies (The Federal Law, latest version from 07.04.2020 № 111-FZ).

In short, this says that if one is found undesirable or not permitted to enter Russia, they should leave the territory of Russia; and if the 'undesirable' does not leave, then s/he should be deported by a federal organ of the executive branch of the government (that is, the police or security services). Since the deportation law is formulated as a law on refusing entry (which does not make sense when applied to already-residing migrants) and/or on undesirability (which is also less than logical), we refer to these as the laws on the deportability or the de facto deportation law in order to clarify the definition dictating and informing practice.

How does one become undesirable? Two administrative fines are sufficient according to the law on entry to and exit from Russia. This law regulates and defines the deportability of migrants as being fined two or more times for breaking residence regulations, such as the propiska, a regulation theoretically and practically impossible to follow (Turaeva 2016; Hojaqizi 2008). The regulation of residence and mobility within Russia is controlled through the propiska regime, which restricts the movement of both citizens and migrants (Hojaqizi 2008). Through this system, the number of individuals who became undesirable was rather high, reaching into the millions. According to official statistics from the Federal Migration Service of the Russian Federation, from 2013 to 2014, over three million foreign citizens were deemed deportable for violating these specific federal laws. ${ }^{3}$ These laws regulate two methods of deportation: voluntary and compulsory. Voluntary deportation is enforced at the foreign person's expense, whereas forced deportation is conducted at the state's expense by transferring the person to a special location. 


\section{Deportation practices: semilegal means of deportation}

Certain passages from the abovementioned articles and clauses from federal laws and the Code of Administrative Offences of the Russian Federation both contradict and reinforce each other. The principle of 'non bis in idem' (from the Latin 'not twice against the same [thing]') prohibiting a second prosecution and punishment for a single action is regulated through Article 50 of the Constitution of the Russian Federation, which states: 'No one may be twice judged for one and the same crime'. Contrary to this statement in the Constitution concerning the inadmissibility of punishment twice for the same act, Clause 4 of Article 26 of the Federal Law of 15 August 1996 reads as follows:

[Those who r] epeatedly (twice or more times) within three years are found guilty for breaking administrative laws for committing an administrative offence on the territory of the Russian Federation are subject to deportation.

For violating Clause 4 of Article 26 of the Federal Law-that is, committing (at times, even, not even committing) two minor offences, the executive body has the right to decide on the deportability of offender migrants.

A protocol is drafted naming the offender. Based on this protocol, the offender must pay an administrative fine. This is one punishment. This punishment then results in further punishment for the same offence-specifically, this offence then defines the offender as deportable, resulting in her/his deportation. After the offender pays the administrative fine, s/he faces an additional punishment, namely, deportation. That is, the person is punished twice for the same offence, which is not permissible under the Constitution. In order to explain these legal contradictions and how the deportation law is applied in practice, we provide several case studies below in the narratives from victims defended by the second author (Izzat Amon).

Another contradictory aspect to the deportation regime lies in the timing following the actual court proceedings, detention and deportation itself. The timing does not reflect the regulation for the time necessary to enforce court decisions, the time allowed for the possibility of filing an appeal and the actual execution of deportation. Namely, when a victim of the deportation regime is deemed deportable by a court decision, legally and theoretically the victim should be granted time to appeal, typically within ten days. However, deportees are granted three days to leave the country voluntarily following the date of a court decision, which automatically prevents deportees from the possibility of appealing a court decision. Much about the legal contradictions and textual inconsistencies exists within the regulations of migration control regimes in Russia. But, what happens in practice when all these legal texts are put into practice? Below, we provide examples from actual deportation cases, partly demonstrating how the deportation regime works in reality.

\section{The case of Mahmud}

Mahmud, a citizen of Tajikistan, came to Russia at the beginning of 2000s as a migrant. He found a job in a Russian logistics company as a driver. After some 
time, he brought his wife and three children to Russia. In 2014, he received a residence permit (a clean propiska) since he managed to buy a flat, whereby he could finally obtain his propiska. In 2016, he travelled to Tajikistan to visit his parents but was not allowed reentry into Russia. At Domodedovo International Airport, he was informed that his entry into Russia was barred on the basis of Federal Law No. 114, Article 26, Clause 4. Mahmud's family remained in Russia, and he was forced to remain in Tajikistan. The legal process to change the court decision took a year to complete.

Legally, two approaches were taken to defend Mahmud's case. The first was to argue based on his ownership of property within the Russian territory and his family living in Russia. Banning the Appellant from reentry to Russia violated his right to enjoy familial life, guaranteed by Article 8 Clause 1 of the Convention for the Protection of Human Rights and Fundamental Freedoms. Moreover, according to Paragraph 3 of Article 16 of the Universal Declaration of Human Rights (adopted through UN General Assembly Resolution 217 A (III) on 10 December 1948), the family is a natural and fundamental unit of society and carries the right to protection from society and the state.

The second strategy relied on tracing the administrative offences within the last three years to determine if two existed. A lengthy inquiry of his offence history yielded positive results, namely, that he had no more than one offence and that was a traffic violation, for which the fine was paid on time. Moreover, according to Russian regulations, the authorities did not have the right to prohibit a person from using his property. Due to the existing offences (less than two), the Appellant was also illegally punished with the deportation law. After successfully defending him — specifically by appealing the original court decision - a further lawsuit was filed forcing migration services to pay moral and physical damage (in the amount of 3000 Russian roubles) as a consequence of the court decision. Ultimately, he was not paid compensation despite a positive decision from the court to pay damages without any known reasons. The ignoring of the court decision such as paying the compensation is also part of the whole legal regime which uses any gaps and contradictions to the law when it concerns migrants' rights. This legal nihilism at times stems also from the general attitude towards migrants as they are seen as those who can have no rights and can be abused with impunity such as police daily abuse, courts ignoring the rights of migrants and deportation regime just acting on migrants without consideration of laws.

Furthermore, Mahmud's case also reveals how entries in the database of offences are subject to being changed and manipulated. This case shows that a migrant was denied entry on the basis of the deportation law (the 'Law on the Exit and Entry to the Russian Federation'), applied to any migrant who broke laws twice within three years. In the case of Mahmud, he had a clean propiska (given that he owned a flat where he could register legally) and broke a law only once within three years. Yet, he was denied entry on the basis of a court decision against him. Without strong legal support, migrants are typically abandoned by legal regimes, which can remove a specific number of migrants to satisfy quotas. Migrants, thus, become deportable, detainable and are denied entry to Russia. 


\section{The case of Shahrukh}

Here, we use the case of Shahrukh to demonstrate the contradictory legal provisions regulated by Russian law. The following case shows the details of the impunity enjoyed by officials and the system itself, which allows space for a securitised system to render unwanted migrants deportable.

In March 2016, Shahrukh, a Tajikistan citizen, was detained in Moscow on suspicion of having committed a robbery. Shahrukh's wife, a citizen of Russia and an ethnic Russian, actively worked to ensure legal support for her Tajik husband. The investigation of robbery lasted six months, yielding no evidence of Shahrukh's participation in the crime. Thus, the criminal case was dismissed due to a lack of evidence. Despite this outcome, he was not released but instead was transferred from a pretrial detention centre to a special detention centre (deportation centre) for deportees. A district court in Moscow issued a decision to deport Shahrukh. A week later, Shahrukh was deported to Tajikistan, well ahead of schedule set for his deportation. The deportation was carried out before the court decision on the deportation had entered into force. His marriage to a Russian citizen and the existence of two minor children, both of whom were also Russian citizens, did not affect the court's decision nor his subsequent deportation from Russia.

If we follow the procedures used in Shahrukh's case, we see how the entire process from the accusation of robbery to the fast-track deportation without a legal decision on the latter took place. In this process, we find no legal basis for transferring Shahrukh from a pretrial detention centre to a deportation detention centre. Suspecting Shahrukh might be a thief rendered him predestined as deportable at any cost. The case and procedures applied to Shahrukh demonstrate how security officials simply agreed that this migrant should be deported and how it was performed. Any counterarguments in his favour against deportation, such as the existence of his family and children who are Russian citizens, did not interest security officials in the least. His fate was left to the deportation machine, namely, transferring him to the detention centre for deportation. The court, then, becomes a symbolic backdrop, where the deportation decision is made, since the actual deportation of the victim is performed without any legal basis, in this case, without entering the court decision into force (usually there must be time granted to submit an appeal).

This case also provides evidence that any wrong move (more than two administrative fines or other convictions or simply being a suspect) which draws the attention of Russian authorities can end with the deportation of migrants to fulfil quotas without ensuring that procedures follow Russian laws and or adhere to the basic human rights conventions.

\section{The case of Nasrulloh}

Early on a summer morning in 2018, the police knocked on the door of the flat that Nasrulloh, a Tajikistan citizen, and his family rented in a Moscow residential district where other Tajik migrants also lived. Security officers (special forces 
officers) forcibly entered the flat, ordering everyone to lie down on the floor. After a thorough search, all of the flat's residents were brought to the Federal Security Service's central office, commonly referred to as 'Lubyanka' (migrant detention centre), a notorious place which migrants fear most. All of the detainees were interrogated in separate rooms. After two days, everyone but Nasrulloh was released. Nasrulloh was accused of financing terrorism, having allegedly sent his terrorist accomplices 25 million roubles over the past six years.

The following facts were established by the defence: Nasrulloh was not involved in any financing of terrorism. He was trusted by labour migrants, who gave their salaries to Nasrulloh in cash. He then sent this money home to Tajikistan through various money transfer systems to safely coordinate the distribution of his fellow Tajik labour migrants' salaries. Another monetary transaction in cooperation with a Tajik businessman who brought goods from Turkey was also established as having nothing to do with financing terrorism. The process of fact-finding in Nasrulloh's defence took about six months. Although the investigation concluded that Nasrulloh was not involved in terrorism, all of the initial accusations against him were brought to court due to the unwillingness of the law enforcement officers to release Nasrulloh.

During the court hearing, the case related to financing terrorism was reclassified as illegal entrepreneurship, violating Article 171 of the Criminal Code of the Russian Federation, even though Nasrulloh conducted all of these transfers legally. After his hearing, Nasrulloh was again detained and transferred to a special detention centre for foreign citizens (deportation centre). Subsequently, he was deported from Russia and banned for life from returning. It was impossible to establish who took the deportation decision with respect to Nasrulloh. All of the requests submitted by Nasrulloh's lawyer regarding the decision on his deportation were ignored. This deportation case also did not end with Nasrulloh's deportation, but extended to his other family members (his brother) and others within his networks (all Tajik migrants). In total, 30 migrants have been deported as a result of Nasrulloh's case.

This case of a deportation chain clearly illustrates how deportation serves as a tool for getting rid of unwanted or legally speaking 'undesired' migrants for whom suspicion surrounds. Whether false or not, the suspicion alone grants state authorities a reason to get rid of a migrant or an entire group of migrants by using regulations, officers and institutions within the deportation regime.

\section{The case of Khurshid}

Khurshid was a foreman at a construction company and oversaw a team of 28 people who all worked for a Russian businessman named Seriy. Khurshid's team built multistorey buildings, performing the most difficult work with the most responsibility: monolith and lining. Amongst construction workers, Seriy was notorious for his fraudulent actions. Seriy had his krysha (protection within the state system) within law enforcement agencies, namely, within the Ministry of Internal Affairs and the National Security Services (FSB a local abbreviation) of Russia. 
After Khurshid realised that he had been deceived and not been paid for the work he and his construction team had completed, he sought legal support to receive their wages. After communicating with Seriy, the latter became angry and made sure that the construction workers were expelled from their barracks (temporary sleeping quarters for construction workers within the building site or next to it). Furthermore, construction workers were denied access in order to collect their belongings. A nongovernmental organisation (led by one of the authors), which provides support to migrants, decided to organise a public demonstration against Seriy's construction company in front of the construction site where the workers were barred entry. The demonstrations were stopped by Special Security Forces (OMON a local abbreviation), who arrived in several buses and detained all of the participants of the demonstration. Within 24 hours, all 28 peopleKhurshid's entire construction worker team-were deported from Russia by order from a decision from Moscow's Gagarin District Court. Khurshid himself was detained for a violation of Article 213 of the Criminal Code of the Russian Federation and placed in a special detention centre. Four months later, Khurshid was released from the courtroom by court order and placed in a special detention centre (deportation centre) for foreign citizens, where he was held for more than six months before being deported.

This case shows that not only suspects do become undesired and fall under the wheels of the deportation machine, but simply angering a powerful person who is well connected to Russian security circles can end in deportation. As Khurshid's case illustrates, a situation of uncertainty or continuously living under the fear of deportation is created, what De Genova and Peutz (2010) describe as a state of deportability. These fears and uncertainty are the main reasons that allow individuals such as Seriy to deceive migrants en masse. Such deception includes letting migrant construction workers toil for months and then not paying them at the end without fear of facing justice. Yet, there is also the reality that, at worst, all such migrants can be deported at any time. This also happened to the abovementioned migrant demonstrators, who were removed from the streets and subsequently deported en masse.

\section{Deportation as political revenge}

Deportation serves Russian authorities not only by enriching its security officers who search for migrant-victims but also by gaining prominence amongst Russian voters (Russian right-wing populism increased as the number of migrants in Russia increased) who support political steps against migrants. Targeting migrants for deportation proved effective as a 'weapon' (Walters 2018: 1) in exerting pressure on Russia's 'former colonies'-that is, Central Asia. Central Asian dependence upon Russia is well established. In the context of migration, where millions of Central Asian migrants remit most of their earnings to their home countries, it is politically and economically crucial for Central Asian governments that the Russian labour market remains open to their impoverished nationals. 
Labour migrants have become bargaining chips between the Kremlin and the migrants' countries of origin. For example, in 2011, the pilots of an aircraft belonging to a Russian airline were detained after illegally crossing the Tajik border. The pilots were subsequently handed lengthy prison sentences. The Kremlin's reaction was predictable and expected, specifically resulting in the hunt for Tajik migrants, which began immediately after the detention of the Russian pilots. According to official records, within just one week, the courts illegally deported over 3000 Tajik citizens to Tajikistan. Public figures and human rights activists held a press conference on the topic of the illegal deportation of Tajik citizens from Russia and called upon Russian authorities to prevent the use of migrants for political purposes. ${ }^{4}$ This measure (deportation) affected Tajik authorities. They were forced to free the pilots, whereby following the sentencing, the pilots were pardoned by the President of Tajikistan and released. ${ }^{5}$

\section{Deportation regimes: an analysis}

Deportation studies gained increasing attention in scholarly analysis in the early 2000s (De Genova 2002; Peutz 2006; Walters 2002; Kanstroom 2000; Coutin 2003; Gibney 2008) when migration and mobility reached their peaks after the fall of communist regimes and other conflicts escalated following the end of the Cold War in the early 1990s. The internet and increasing global connectivity have served as the primary engines fuelling mobility and the globalisation of markets and capital.

The deportation regime gained prominence with global political insecurities concerning state sovereignty, whilst the securitisation of migration expanded further afield (Coutin 2015; Bleichmar 1999; Drotbohm 2014; Drotbohm and Hasselberg 2014; Galvin 2014; Hasselberg 2014; Kanstroom 2000, 2012; Schuster and Majidi 2014; Walters 2002). Deportation became the primary tool to control migration and mobility (De Genova 2002; De Genova and Peutz 2010; Dreby 2012, 2013; Peutz 2006). According to De Genova and Peutz (2010: 34), 'the practice of deportation has nonetheless emerged as a definite and increasingly pervasive convention of routine statecraft'. Furthermore, these deportation practices became a 'global regime' of controlling mobility and migration (De Genova and Peutz 2010: 34).

De Genova distinguished between the legal process of deportation (from above) and the state of being deportable (from below), not so much as the legal status of a person but as something experienced and perceived (living in fear), full of uncertainties and living with the risk of being deported every day. He describes this state of being amongst migrants as an 'enforced orientation to the present' (De Genova 2005: 427). Central Asian migrants also live with a constant worry that their businesses or economic activities will be stopped at any moment, filling them with the drive to make the best of the present or to think only in the short term. A continuous state of being deportable contributes to the vulnerability of migrants to exploitation, violence and abuse. Remaining silent and bearing injustice then represents an important strategy to continue longer without being 
deported. Experiences of this state of deportability are accompanied by multiple sacrifices to freedom, rights, honour and the enjoyment of life.

In all of the deportation cases presented in this chapter, we described the means and methods used to produce deportability, where legal instruments have been abused and used as weapons to fight migration and to gain political recognition amongst Russian voters. The deportation regime was created after the fall of the Soviet Union in order to fight migration and increased mobility, which challenged not only rigid national boundaries, but also authoritarian regimes. Migrants are 'undesirable' not only in the destination country (Russia) but also in their homes by their governments, for whom they symbolise poverty and weaknesses related to the inability to manage their economies such that their citizens are forced to leave their countries. The latter brings the home governments (in Central Asia) into a bad light. For the Russian economy, although cheap migrant labour fill jobs Russian citizens would not like to do remains crucial to maintaining the economy, the Russian government is challenged by the high numbers of mass migration and must negotiate with the mood of Russian voters. The deportation regime is then an easy tool to manage the number of migrants. As we have also seen in one of the case studies presented in this chapter, not only do Russian government actors play a role, but so, too, do the governments of the sending countries which must cooperate with the former. Cooperation with several nation-states in order to manage mobility is a normal practice, but using migrants in political games such as revenge is anything but normal.

Besides employing deportation as a weapon (Walters 2018: 1) and punishment (Navasky 1959), in the hands of powerful actors poor migrants not only experience deportation during the process itself but a priori state of deportability symbolises the daily struggle played out through abusive and deceptive employers, police on the street, neighbours or simply others. Knowledge about the deportability of migrants is widely shared through political promotions and media coverage, which do not necessarily serve as a criticism of the mechanism, but rather protect those who can easily abuse this weapon through exploitation as employers, violence in the street against migrants, enforcing obedience and silencing migrants. The creation of such dependencies and power relations between migrants and others in power has a number of implications for the vulnerability of migrants and for the security of their families.

\section{Conclusions}

We provided here examples of deportation cases, some personally defended by the second author, some involving court hearings the first author attended and some handled by both authors during field research conducted in Moscow in 2016, 2017, 2018 and 2019. We also noted that deportation cases statistically increased after the procedure was put into practice in 2013 based on the personal experiences of the second author as a practising lawyer. The number of the deportation cases reached millions, where holders of Russian passports with Central Asian ethnicity fell victim to the same deportation regime detailed in this chapter. In cases 
involving Russian passport holders with Central Asian ethnicity, the procedure of deportation followed the same pattern described by Agamben (1998), a pattern which lies somewhat beyond our scope here. Agamben (1998) and his Homo Sacer namely follows the same patterns such as individuals were first taken their identity papers away in order to act upon their pure bodies or 'bare life', where a human being without his official and civic papers is nothing more than flesh and soul. Agamben brings the example of Nazi camps where Jews and others have been exploited and killed only after the civic rights have been taken away from the victims. The same pattern follows the deportation cases where Russian citizens with Central Asian origin are deprived of their citizenships first and then deported to their countries of origin. The astonishing number of deportation cases against migrants in Russia who entered legally due to the visa-free regime speaks for itself. Beyond the statistical reality of deportation from Russia, we presented an in-depth analysis of the deportation regime, where not only state interests (national sovereignty and migration control) were supported, but we also show that there were additional interests and cooperation involved within the deportation regime such as collaboration with state officials from the deportees' countries of origin. In this chapter, we demonstrated that Russia's deportation regime not only concerns individuals who violated border-crossing regulations and should be deported, but we also identified a process of politicising deportation, which is becoming more relevant and an increasingly important machine for getting rid of unwanted migrants. We also noted a correlation between deportation and political events regarding, for instance, the arrest of Russian pilots in Tajikistan, which clearly indicates a process of politicising the deportation regime.

Furthermore, we highlighted contradictory and paradoxical aspects of the Russian legal basis of the deportation regime, whereby it is clear that legal provisions were not necessarily adhered to within the practice of deportation, including the speed of the actual execution of a deportation or finding reasons for a deportation. We argue that the lack of a clear regulatory basis for making decisions about deportation, as well as the legal violation of laws during the process of deportation, results in a chaotic management of migration and mobility, opening space for police abuse. We also argue that these gaps and contradictions serve as the means and an opportunity for Russian officials to illegally expel unwanted migrants from Russia, specifically by using and abusing deportation as a weapon or punishment, mirroring findings from Walters (2002) and Navasky (1959). The overall analysis of the practice of deportation and the violation of the human rights of migrant-victims indicates and supports the findings of De Genova (2019), such that deportability is both produced and experienced.

It is not only the contradictions and gaps in the legal system that create these opportunities but, also, as we demonstrated above, the impunity of employees who overstep their privileges and authority through, for example, their unhindered access to databases which can be manipulated if necessary. These opportunities grant state officials rights over the lives and livelihoods of many labour migrants.

The continuous state of deportability renders migrants vulnerable to various kinds of exploitation and violence, keeping migrants dependent upon those in 
power. Mobility, migration and uncertainties formed the central topics of this chapter, which contributes to general debates about informality and mobilities. Furthermore, our work contributes to an understanding of how uncertainties are produced through a continuous state of deportability and how mobility or limitations to it lead to violations of the basic human rights to mobility and the freedom of movement. Informal and, at times, the illegal application of rules and laws to practise deportation also reveal how much flexibility is possible within Russian legislation in order to easily punish individuals classified as unwanted or, to use Russian legal text wording, 'undesirable' (nejelatelnost').

\section{Notes}

1 It should, however, be noted that the statistics presented here require revision in light of the COVID-19 pandemic, which led thousands of migrants to return to their home countries.

2 Rosstat migration data for the years 2011-2017, available online via https://showdata .gks.ru/report/276650/ [accessed 24.03.2020]

3 A later law, 'On the Violation by Foreign Citizens or Stateless Person of the Rules of Entry into the Russian Federation or the Regime of Stay (Residence) in the Russian Federation', was mentioned in Article 18.8 of the Code of Administrative Offences of the Russian Federation, dated 30 December 2001 (No. 195-FZ). Additions and amendments to the law were introduced in 2004, 2006 and 2018. Furthermore, on 30 December 2001, the 'Law on the Illegal Implementation by Foreign Citizens or Stateless Persons of Labour Activities in the Russian Federation' was incorporated into the Code of Administrative Offences of the Russian Federation. Changes and amendments to the law were introduced in 2006 and 2018.

4 'Russia has not calmed down: Tajiks will continue to be expelled from the country, despite the completion of the pilots' case'. The article was published in Newsru.c om on 23 November 2011. http://www.newsru.com/russia/23nov2011/tajikistan.html [accessed 17.08.2020]

5 Oleg Kiryanov, 'Released in the courtroom: In Tajikistan, the verdict against the Russian and Estonian pilots was reviewed'. 23 November 2011. Rossiyskaya GazetaFederal issue No. 263 (5639). Published online under: https://rg.ru/2011/11/22/sudsite.html [accessed 17.08.2020]

\section{References}

Agamben, Giorgio. 1998. Homo Sacer. Sovereign Power and Bare Life. Translated by Daniel Heller-Roazen. Stanford: Stanford University Press.

Appadurai, A. 1996. Modernity al Large: Cultural Dimensions of Globalization (Vol. 1). Mineapolis and London: University of Minnesota Press.

Bigo, Didier. 2002. "Security and Immigration: Toward a Critique of the Governmentality of Unease." Alternatives: Global, Local, Political 27 (Suppl. 1): 63-92.

Bleichmar, Javier. 1999. "Deportation as Punishment: A Historical Analysis of the British Practice of Banishment and Its Impact on Modern Constitutional Law." Georgetown Immigration Law Journal 14: 115.

Calavita, Kitty. 2005. Immigrants at the Margins: Law, Race, and Exclusion in Southern Europe. Cambridge: Cambridge University Press.

Chavez, Leo R. 2008. The Latino Threat: Constructing Immigrants, Citizens, and the Nation. Stanford: Stanford University Press. 
Cole, David. 2002. "Enemy Aliens." Stanford Law Review 54 (5): 953-1004. doi:10.2307/1229690.

Cornelius, Wayne A., Philip L. Martin, and James F. Hollifield, eds. 1994. Controlling Immigration: A Global Perspective. Stanford: Stanford University Press.

Coutin, S. B. 2003. "Suspension of Deportation Hearings and Measures of 'Americanness'." Journal of Latin American Anthropology 8: 58-94. doi:10.1525/jlca.2003.8.2.58.

Coutin Susan Bibler. 2015. "Deportation Studies: Origins, Themes and Directions." Journal of Ethnic and Migration Studies 41 (4): 671-681. doi:10.1080/1369183X.2014.957175

De Genova, N. 2019. "Detention, Deportation, and Waiting: Toward a Theory of Migrant Detainability." Gender a Výzkum 20 (1): 92-104.

De Genova, Nicholas. 2002. "Migrant 'Illegality' and Deportability in Everyday Life." Annual Review of Anthropology 31 (1): 419-447. doi:10.1146/annurev. anthro.31.040402.085432.

De Genova, N. 2005. Working the Boundaries: Race, Space, and "illegality" in Mexican Chicago. Durham and London: Duke University Press.

De Genova, Nicholas, and Nathalie Peutz. 2010. The Deportation Regime. Durham: Duke University Press.

Djelic, M.L. and Sahlin-Andersson, K. eds. 2006. Transnational Governance: Institutional Dynamics of Regulation. Cambridge: Cambridge University Press.

Doty, Roxanne Lynn. 1998. "Immigration and the Politics of Security." Security Studies 8 (2-3): 71-93. doi:10.1080/09636419808429375.

Dreby, Joanna. 2012. "The Burden of Deportation on Children in Mexican Immigrant Families." Journal of Marriage and Family 74 (4): 829-845. doi:10.1111/j.1741-3737.2012.00989.x.

Dreby, Joanna. 2013. "The Modern Deportation Regime and Mexican Families." In Constructing Immigrant "Illegality”: Critiques, Experiences, and Responses, edited by Cecilia Menjívar and Daniel Kanstroom, 181-202. Cambridge: Cambridge University Press.

Drotbohm, H. 2014. “The Reversal of Migratory Family Lives: A Cape Verdean Perspective on Gender and Sociality Pre- and Post-Deportation." Journal of Ethnic and Migration Studies. doi:10.1080/1369183X.2014.961905.

Drotbohm, H., and I. Hasselberg. 2014. "Editorial Introduction to Deportation, Anxiety, Justice: New Ethnographic Perspectives." Journal of Ethnic and Migration Studies. doi $: 10.1080 / 1369183 X .2014 .957171$.

Ellermann, Antje. 2009. States against Migrants: Deportation in Germany and the United States. Cambridge: Cambridge University Press.

Fassin, Didier. 2011. "Policing Borders, Producing Boundaries. The Governmentality of Immigration in Dark Times." Annual Review of Anthropology 40 (1): 213-226. doi:10.1146/annurev-anthro-081309-145847.

Foucault, M. [1975] (1977b). Discipline and Punish: The Birth of the Prison. New York: Vintage.

Foucault, M. 1980. Power/Knowledge: Selected Interviews and Other Writings, 19721977. New York: Pantheon Books.

Galvin, T.M. 2014. “'We Deport Them but They Keep Coming Back': The Normalcy of Deportation in the Daily Life of 'Undocumented' Zimbabwean Migrant Workers in Botswana." Journal of Ethnic and Migration Studies. doi:10.1080/13691 83X.2014.957172.

Gibney, M. J. 2008. "Asylum and the Expansion of Deportation in the United Kingdom." Government and Opposition 43: 146-167. doi:10.1111/j.1477-7053.2007.00249.x. 
Glick Schiller, N., Basch, L., Blanc-Szanton, C., eds. 1992. Towards a Transnational Perspective on Migration: Race, Class, Ethnicity, and Nationalism Reconsidered. New York: NY Academy of Science.

Guild, E. 2009. Security and Migration in the 21st Century. Cambridge: Polity Press.

Gupta, A. and Ferguson, J. eds. 1997. Culture, Power, Place: Explorations in Critical Anthropology. Durham and London: Duke University press.

Hannerz, U. 1996. Transnational Connections: Culture, People, Places. London and New York: Taylor \& Francis US.

Hart, K. 2006. "Bureaucratic Form and the Informal Economy". In: B. Guha-Khasobis; R. Kanbur and E. Ostrom, eds. Linking the Formal and Informal Economies: Examples from Developing Countries. Oxford University Press, 21-35. ISBN 9780199204762.

Hasselberg, I. 2014. "Balancing Legitimacy, Exceptionality and Accountability: On Foreign-national Offenders' Reluctance to Engage in Anti-deportation Campaigns in the UK." Journal of Ethnic and Migration Studies. doi:10.1080/1369183X.2014.957173.

Heusala, A.L. and Aitamurto, K. eds. 2016. Migrant Workers in Russia: Global Challenges of the Shadow Economy in Societal Transformation. London and New York: Taylor \& Francis.

Hojaqizi, G. 2008. "Citizenship and Ethnicity: Old Propiska and New Citizenship in PostSoviet Uzbekistan.” Inner Asia 10(2): 305-322.

IOM. 2005. World Migration 2005: Costs and Benefits of International Migration. Volume 3 - IOM World Migration Report Series. Geneva: IOM.

Kanstroom, Daniel. 2000. "Deportation, Social Control, and Punishment: Some Thoughts about Why Hard Laws Make Bad Cases.” Harvard Law Review 113 (8): 1890-1935. doi:10.2307/1342313.

Kanstroom, Daniel. 2012. Aftermath: Deportation Law and the New American Diaspora. Oxford: Oxford University Press.

Krause, Keith, and Michael C. Williams. 1996. "Broadening the Agenda of Security Studies: Politics and Methods." Mershon International Studies Review 40 (2): 229-254. doi: $10.2307 / 222776$.

Ledeneva, A. 1998. Russia's Economy of Favours: Blat, Networking, and Informal Exchange. Cambridge: Cambridge University Press.

Ledeneva, A. 2006. How Russia Really Works: Informal Practices in the 1990s. Ithaca: Cornell University Press.

Navasky, V. S. (1959). “Deportation as Punishment." University Kansas City Law Review 27 (4): 213-234, University of Kansas City Press.

Nevins, Joseph. 2002. Operation Gatekeeper: The Rise of the "Illegal Alien" and the Making of the US-Mexico Boundary. New York: Routledge.

Peutz, Nathalie. 2006. "Embarking on an Anthropology of Removal." Current Anthropology 47 (2): 217-241. doi:10.1086/498949.

Schenk, C. 2020. "Migrant Rights, Agency, and Vulnerability: Navigating Contradictions in the Eurasian Region." Nationalities Papers 48(4): 637-643.

Schiller, N. G., Basch, L., and Blanc, C.S. 1995. "From Immigrant to Transmigrant: Theorizing Transnational Migration.” Anthropological Quarterly: 48-63.

Schuster, L., and Nassim Majidi. 2014. "Deportation Stigma and Re-migration.” Journal of Ethnic and Migration Studies. doi:10.1080/1369183X.2014.957174.

Simon, Jonathan. 1998. "Refugees in a Carceral Age: The Rebirth of Immigration Prisons in the United States." Public Culture 10 (3): 577-607. doi:10.1215/08992363-10-3-577.

Stumpf, Juliet P. 2006. "The Crimmigration Crisis: Immigrants, Crime, and Sovereign Power." American University Law Review 56 (2): 367-419. 
Tsing, Anna. 2005. Friction: An Ethnography of Global Connection. Princeton, NJ: Princeton University Press.

Turaeva, R. 2013. "Post-Soviet Uncertainties: Micro-orders of Central Asian Migrants in Russia.” Inner Asia 15 (2): 273-292.

Turaeva, R. 2014. "Mobile Entrepreneurs in Post-Soviet Central Asia: Micro-Orders of Tirikchilik." Communist and Post-Communist Studies 47 (1): 105-114.

Turaeva, R. 2018. "Informal Economies in Post-Soviet Space: Post-Soviet Islam and its Role in Ordering Entrepreneurship in Central Asia." Central Asian Affairs 5: 55-75.

Urinboyev, R. 2019. Everyday Corruption and Social Norms in Post-Soviet Uzbekistan.

Urinboyev, Rustamjon, and Abel Polese. 2016. "Informality Currencies: A Tale of Misha, His Brigada and Informal Practices among Uzbek Labour Migrants in Russia." Journal of Contemporary Central and Eastern Europe 24 (3): 191-206.

Urry, J. 2012. Sociology Beyond Societies: Mobilities for the Twenty-first Century. London and New York: Routledge.

Vertovec, S. 2009. Transnationalism. London and New York: Routledge.

Walters, William. 2002. "Deportation, Expulsion, and the International Police of Aliens." Citizenship Studies 6 (3): 265-292. doi:10.1080/1362102022000011612.

Walters, William. 2018. "Aviation as Deportation Infrastructure: Airports, Planes, and Expulsion." Journal of Ethnic and Migration Studies 44 (16): 2796-2817.

Welch, Michael. 2002. Detained: Immigration Laws and the Expanding INS Jail Complex. Philadelphia: Temple University Press.

Welch, Michael. 2006. Scapegoats of September 11th: Hate Crimes \& State Crimes in the War on Terror. Piscataway: Rutgers University Press.

Willen, Sarah S. 2007. "Toward a Critical Phenomenology of 'Illegality': State Power, Criminalization, and Abjectivity among Undocumented Migrant Workers in Tel Aviv, Israel." International Migration 45 (3): 8-38. doi:10.1111/j.1468-2435.2007.00409.x.

Williams, Michael C. 2003. "Words, Images, Enemies: Securitization and International Politics." International Studies Quarterly 47 (4): 511-531. doi:10.1046/j.0020-8833.2003.00277.x. 